\title{
Andrea Bernasconi's Earliest Operatic Music on its Way North of the Alps
}

Metoda Kokole / metoda.kokole@zrc-sazu.si

Institute of Musicology, Research Centre of the Slovenian Academy of Sciences and Arts, SL

\begin{abstract}
In contrast to the relative thoroughness of research into the life and works of Andrea Bernasconi for the period after his arrival in Munich in 1753, his earlier biography still has many lacunae. Following on from the author's earlier identification of Bernasconi's setting from 1736 of the opera Adriano in Siria for the Royal and Ducal Theatre in Milan, this article analyses the extant score and libretto of his Flavio Anicio Olibrio, produced in January 1737 at the Kärntnertor Theatre in Vienna. Interestingly, this production included four arias from Bernasconi's earlier Adriano and is the source for seven manuscript copies of Bernasconi arias in the Attems collection today preserved in Maribor, Slovenia. Viennese music circles are thus identifiable as one of the sources for this collection. From Vienna Bernasconi's music had already reached Moravia by 1737 , and from Milan it was already being sought in late 1736 by the Württemberg Court in Stuttgart. The two discussed operas thus paved the way for the early reception and popularity of Bernasconi's arias north of the Alps.
\end{abstract}

\section{Keywords}

Andrea Bernasconi (1706-1784), his earliest operas, Adriano in Siria (Milan 1736), Flavio Anicio Olibrio (Vienna 1737), reception of arias, Styria, Moravia, Württemberg

This article is a result of a research programme (P6-0004) financed by the Slovenian Research Agency (ARRS). 


\section{Andrea Bernasconi (1706-1784) and his early career}

The literature on the prolific eighteenth-century composer Andrea Bernasconi is surprisingly rather sparse. Apart from short general articles on his life and works in the most recent printed versions of the major music encyclopedias Die Musik in Geschichte und Gegenwart of 1999 and The New Grove Dictionary of Music and Musicians of 2001 both articles are also available in online editions, but without any revisions or updates ${ }^{1}$ - only two extensive writings have up till now been dedicated to Andrea Bernasconi: a doctoral dissertation by Eduard Josef Weiss on the subject of Andrea Bernasconi as a composer of opera published in 1923 (and thus nearly a hundred years old) ${ }^{2}$ and a monograph from 2010, likewise based on a doctoral dissertation, by Daniela Sadgorski, which deals with Bernasconi and the operas he wrote for the Bavarian court in Munich between 1753 and $1772 .{ }^{3}$

Even though Andrea Bernasconi is not very well known today, he was rather popular in his own time and was also remembered, together with his stepdaughter and singer Antonia, very shortly after his death in 1790 in Ernst Ludwig Gerber's famous HistorischBiographisches Lexicon der Tonkünstler. ${ }^{4}$ However, none of these sources provides much information on Bernasconi's early musical career, a subject that came to my attention in 2012 by pure chance through a musical discovery - a quantity of Italian opera arias bearing this composer's name. These manuscripts were located in Maribor, Slovenia, and date from before $1744 .{ }^{5}$

Andrea Bernasconi was born in 1706 in Marseilles to a father who was at the time an army officer. ${ }^{6}$ When his father retired from the army, the family moved to Parma and

1 MÜNSTER, Robert. Bernasconi, Andrea. In Die Musik in Geschichte und Gegenwart Online. [2017-5-8]. URL: <https://www-mgg-online-com.nukweb.nuk.uni-lj.si/article?id=mgg01419\&cv=1.0\&crs=id-4fd15a83-28b47db1-d9d8-3abf0bd26fe8> and MÜNSTER, Robert - CORNEILSON, Paul. Bernasconi, Andrea. In Grove Music Online. [cit. 2018-1-25]. URL: <http://www.oxfordmusiconline.com.nukweb.nuk.uni-lj.si/subscriber/article/ grove/music/02864>.

2 WEISS. Eduard Josef. Andrea Bernasconi als Opernkomponist. PhD Munich, 1923.

3 SADGORSKI, Daniela. Andrea Bernasconi und die Oper am Münchner Kurfürstenhof 1753-1772. Munich: Herbert Utz Verlag, 2010.

4 GERBER, Ernst Ludwig. Bernasconi (Andrea). Historisch-Biographisches Lexicon der Tonkünstler, welches Nachrichten von dem Leben und Werken musikalischer Schriftsteller, berühmter Componisten, Sänger, Meister auf Instrumenten, Dilettanten, Orgel- und Instrumentenmacher, enthält. Vol. 1. Leipzig: Johann Gottlob Immanuel Breitkopf, 1790, col. 146 .

5 Pokrajinski arhiv Maribor, Gospoščina Bistriški grad, Musicalia, TE 67, AE 1; cited hereafter as SI-Mpa. For the catalogue and the context of this collection, see KOKOLE, Metoda. Migrations of Musical Repertoire. The Attems Music Collection from Around 1744. In Musicians' Mobilities and Music Migrations in Early Modern Europe. Biographical Patterns and Cultural Exchanges. Gesa zur Nieden - Berthold Over (eds.). Bielefeld: Transcript Verlag, 2016, pp. 341-377. The arias identified up to 2015 as compositions by Andrea Bernasconi, especially ones belonging to a production of Adriano in Siria, are discussed in KOKOLE, Metoda. Did Andrea Bernasconi Compose 'Adriano in Siria' Twice? In Music Migration in the Early Modern Age: Centres and Peripheries - People, Works, Styles, Paths of Dissemination and Influence. Jolanta Guzy-Pasiak - Aneta Markuszewska (eds.). Warsaw: Liber Pro Arte, 2016, pp. 337-362.

6 The following short account of Bernasconi's life is drawn from Sadgorski's monograph unless otherwise 
became engaged in trade. Nothing is known of Andrea's schooling, whether formal or informal: it seems, at any rate, that he had no professional education in music, since he was called in his earliest known works - those dating from 1737 to 1742 - a dilettante, a term that possibly hints at a quite high social status for Bernasconi's family, for persons of such origin could easily be very good musicians and also composers, such as Tomaso Albinoni, even if they could hardly be regarded as professionals.

Nearly everything we know today about Bernasconi's earlier life comes from printed libretti and annotations on the widely dispersed copies of his arias. According to the musicological literature, his operas from the period up to 1744 were staged in Vienna, Venice, Padua, Lucca, Turin and Rome. Between 1744 and 1753 Bernasconi spent most of his time in Venice as maestro di coro at the Ospedale della Pietà. From 1753 onwards we find him at the Wittelsbach Court in Munich, and by 1755 he has already been appointed its Kapellmeister, thereby becoming one of the best paid and most fashionable musicians at the Bavarian Court. ${ }^{7}$ He remained in Munich until his death in 1784.

During his lifetime Bernasconi composed more than twenty opere serie. Many of these he set to music more than once. In his later years, however, he composed mostly sacred music, including masses and numerous other liturgical compositions for the Wittelsbach court. Most of this music was lost through fire during World War II. Andrea Bernasconi's operatic style remained conservative even in his late period, which coincided with major changes of taste and style in the operatic genre throughout Europe.

Of the seventeen dramatic works by Bernasconi belonging to the period before his arrival to Munich that are listed in Daniela Sadgorski's book, two are serenatas and three are operas that were either produced twice (Temistocle) or set to music more than once (Antigono and Alessandro Severo, also performed under the name of Salustia). ${ }^{8}$ Many of the operas by Bernasconi written for his employer in Munich were his second settings or reworkings of individual operas: for example, Temistole, Didone and Bajazet.

Sadgorski's list cites seven titles of opere serie composed up to 1744 during the years preceding his obtaining a more stable position in Venice. Significantly, the year 1744 is the latest possible date for the pieces preserved in Maribor that formed the focus of my original research. My present discussion accordingly concentrates on Bernasconi's very first operas, since my attempts to match operatic texts of his later operas with texts of the preserved music in Maribor have not yielded any positive result.

indicated. The earliest literature has proved to be unreliable and contains noticeable lacunae in its information on his works. Gerber, for example, states that the composer was "aus Verona" and gives the titles of only eight of his operas, starting with the Alessandro Severo of 1741. GERBER, op. cit., col. 146.

7 On Bernasconi's financially successful career in Munich, see also KÄGLER, Britta. Competition at the Catholic Court of Munich. Italian Musicians and Family Networks. In Musicians' Mobilities and Music Migrations in Early Modern Europe. Biographical Patterns and Cultural Exchanges. Gesa zur Nieden - Berthold Over (eds.). Bielefeld: Transcript Verlag, 2016, pp. 81-84.

8 SADGORSKI, op. cit., 50. An exhaustive list of Bernasconi's works is also available in MÜNSTER - CORNEILSON, op. cit. 


\section{The Milanese Adriano in Siria - Bernasconi's earliest known opera}

In my recent article entitled "Did Andrea Bernasconi composed Adriano in Siria twice?"9 I argued that Bernasconi set to music Metastasio's libretto for Adriano in Siria already in late 1735 in preparation for the production in Carnival 1736 at the Royal and Ducal Theatre of Milan. This version was musically completely different from the well-known and fully documented Adriano in Siria composed by the recently appointed vice-maestro di cappella of the Wittelsbach court in Munich in 1755. The argument in my article of 2016 was based on a comparison of the two extant libretti - for the productions in Milan (1736) and in Munich (1755; the complete score by Bernasconi is also preserved) - and the music of as many arias as I could find on the basis of texts originally written by Metastasio for his Adriano in Siria and of musical manuscripts predating 1744 and possibly naming Bernasconi as composer.

The Viennese court poet Pietro Metastasio wrote Adriano in Siria in 1732 on a commission from the Holy Roman Emperor Charles VI for the opera to be composed by Antonio Caldara for a performance at the Kärntnertor Theatre. During the remainder of the eighteenth century this libretto was very popular and received at least sixty different settings; up to the year 1744 alone fifteen composers are known to have set music to this text. Metastasio's original libretto contains twenty-six arias. Although the preserved wordbook for the Carnival 1736 production in Milan does not name the librettist, the text is certainly Metastasio's, with two replacement arias duly identified before the opening of Act I and some other minor changes. ${ }^{10}$

To my present knowledge, no preserved musical score corresponds to the Milanese production in 1736 of Adriano in Siria. I came to suspect the relevance of this production only through a systematic search for early arias by Andrea Bernasconi that matched the music discovered in Maribor. In that collection, originally belonging to Countess Josepha von Attems, who resided in Graz and Slovenska Bistrica, there are five arias bearing Bernasconi's name. Three of these are settings of Metastasio's arias for Adriano in Siria. Further, four anonymous arias from the same collection were likewise identifiable - through the RISM database and a comparison of the music itself with that of other sources - as settings by Bernasconi of aria texts from Adriano in Siria not matching the music of his setting of $1755 .{ }^{11}$ Most of the concordant sources have the composer clearly indicated as Andrea Bernasconi. One matching aria, however, is misattributed to Filippo Finazzi, who was probably its singer on some occasion and as such had his name written on the score.

9 KOKOLE, op. cit. (Did Andrea Bernasconi ...).

10 SARTORI, Claudio. I libretti italiani a stampa dalle origini al 1800. Catalogo analitico con 16 indici (vol. 1). Cuneo: Bertola \& Locatelli, 1990, p. 35 (no. 372). A scan of the original print by Giuseppe Richino Malatesta of Milan from 1735 (a digitized copy of I-Mb, Racc. Dramm. 6048/3) is available online through the OPAC SBN.

11 See Appendix 1 for an updated list of Bernasconi's identified arias preserved in the so-called Attems collection; this list contains information on concordant music sources located elsewhere. 
The four manuscript sources for the aria Se non ti moro allato from Act I, Scene 15 (see the list in Appendix 1) were especially important - indeed, decisive - for my final result. They all differ from Bernasconi's 1755 setting of the same text. All except the version from Maribor were copied in standard score formats for voice, basso continuo, two violins and viola. In contrast, the copy in Maribor lacks any instrumental introduction and is presented merely as a short score for voice and instrumental bass. ${ }^{12}$ At least two of the collated manuscripts originate similarly from the period leading up to 1741 .

The one from Chicago belongs to a collection of 22 manuscript items, most of them copies of arias from operas produced in Rome and north Italian theatres between about 1737 and 1741. The collection with the call number 1267 was acquired by Chicago University in the early 1980s. ${ }^{13}$ According to those who have so far investigated the collection, the first owner was an amateur singer, probably a gentleman on the Grand Tour with a good musical training and some amateur skills.

The second collated source has a very definite origin. It is one of the bound fascicles of musical scores brought back from his Grand Tour in Italy (1739-1741) by an English pre-Romantic poet of international fame: Thomas Gray. ${ }^{14}$ Gray's musical collection is today stored in the Lewis Walpole Collection at Yale University. ${ }^{15}$ Bernasconi's aria $S e$ non ti moro allato is the thirtieth piece in volume 9 of Gray's collection, which consists largely of pieces that can be safely dated between 1737 and 1740. Gray named the composer as "Andrea Bernasconi Milanese", noted the opera (Adriano) and added the role: "Farnaspe".

The third collated copy, today in Münster, comes from a collection of arias once owned by the collector Fortunato Santini. ${ }^{16}$ All the compared musical manuscripts are in the same key and have the identical tempo marking. On this copy only the name of the composer is indicated. The information gleaned from these various copies supports the hypothesis of a production of Adriano in Siria by Bernasconi "dilettante Milanese" (or else a pasticcio with his music) that predates 1741 .

The seven pieces from the Attems collection, in addition to a further nine arias preserved in Germany, Belgium and Austria, match perfectly the preserved libretto of the Milanese Adriano in Siria of 1736. Moreover, six of these concordant music manuscripts include the description "dilettante", or even "dilettante milanese", after the composer's surname. One copy supplies the name of the singer and/or first owner, Signor Carestini, who indeed interpreted Adriano in the Milanese production in question.

12 Such short scores were used by operatic singers rehearsing their parts (possibly accompanying themselves on the keyboard), and also for informal chamber performance outside the opera house.

13 US-Cc; Ms. 1267.

14 US-Fay; Quarto 532 MS 9.

15 For more on music and Thomas Gray's collection, see KOKOLE, op. cit. (Did Andrea Bernasconi...), pp. 253-254, and KOKOLE, Metoda. The Lasting Musical Effects of the Italian Grand Tours of Ignaz Maria von Attems-Heiligenkreutz (1714-1762) and Thomas Gray (1716-1771). Arti musices, 2016, vol. 47, no. 1-2, pp. 90-98.

16 D-MÜs; SANT Hs 183; Nr. 12. 
Collectively, these arias - hypothetically - account for over half of the aria texts in the Milanese libretto of 1736, so I suggest that this was indeed an initial setting of Metastasio's libretto, written by "Signor Bernascone Milanese, dilettante" for his native city of Milan. Perhaps it was the composer's first, or one of his earliest, operas dating from earlier than 1737 that Eduard Josef Weiss supposed might have had existed. It is also important to note that the capital of Lombardy, Milan, was at that time - as it had been since 1713, following the War of the Spanish Succession - an imperial possession; therefore, its connection to the imperial capital, Vienna, was of some relevance.

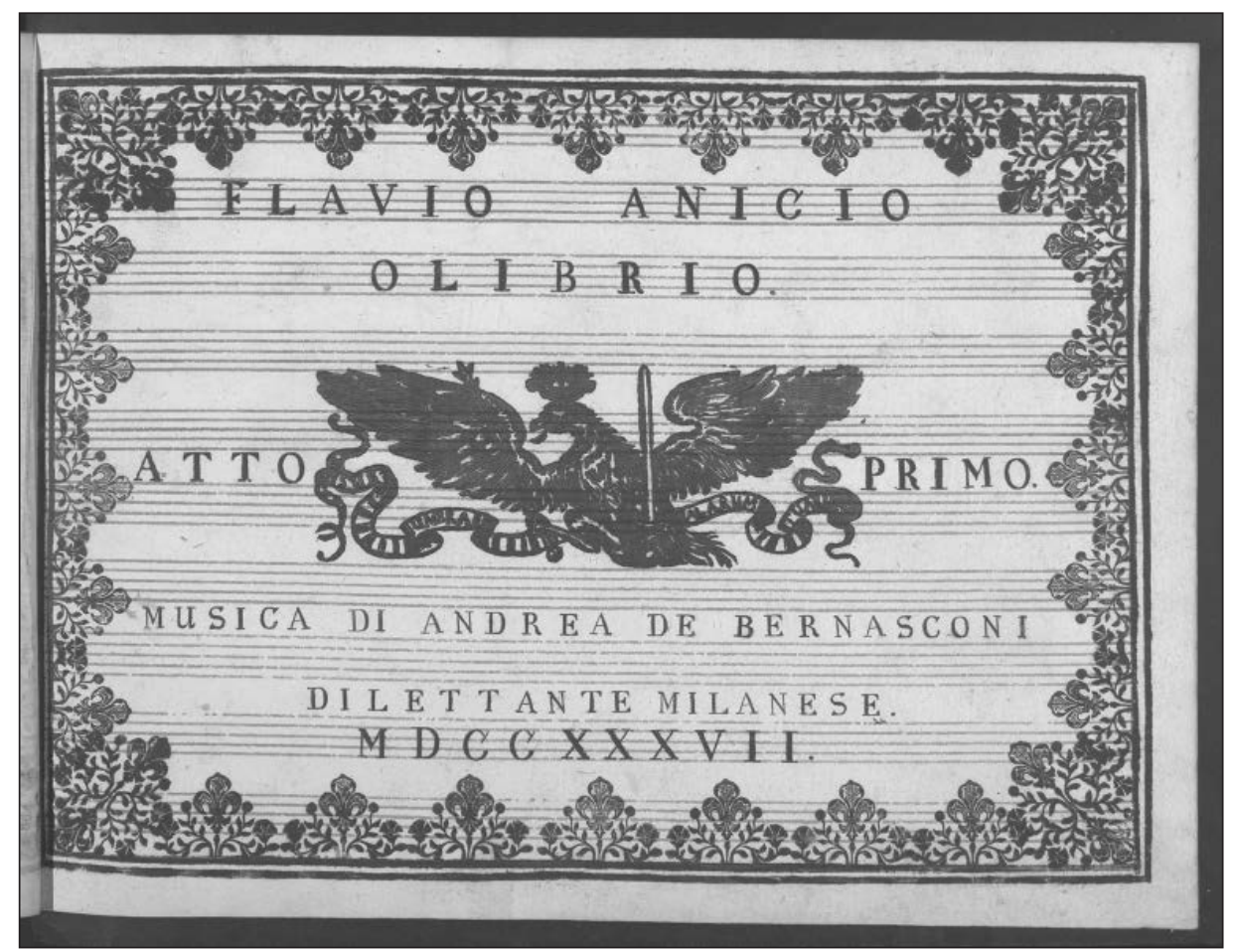

Fig. 1

Title page of the 1737 score of Flavio Anicio Olibrio by Andrea Bernasconi (A-Wn, Musiksammlung; Mus.Hs. 18294/1, with kind permission)

\section{Flavio Anicio Olibrio of 1737 for the Viennese Kärntnertor Theatre}

The existence of an earlier opera for Milan would also explain why Andrea Bernasconi was styled "dilettante Milanese" in the fair copy of his opera Flavio Anicio Olibrio dated 1737 that is preserved, among other musical works from the Viennese Hofkapelle, in 
the National Library in Vienna. ${ }^{17}$ The matching libretto survives in a single copy today held by the library of the Vienna town hall (Wienbibliothek im Rathaus). ${ }^{18}$ The libretto is bilingual, with Italian and German texts on facing pages. The title page has the Italian title in the upper part of the opening page and the German one in the lower part. The city and the name of the printer appear at the foot of the page, in German-style lettering only, as: "FLAVIO ANICIO / OLIBRIO. / DA CANTARSI / NEL / TEATRO / Privilegiato da S.M.C. e Cat. / In VIENNA. / Nell'anno MCCCXXXVII. / Nel mese di Gennajo. // FLAVIUS ANICIUS / OLIBRIUS. / In einem / MUSICA- / lischen Schau=Spiel / Auf dem Kaiserlich=Privilegirten / Theatro in Wien / Vorgestellet / Im Jahr 1737. im Monat Januario. // Wien - Gedruckt bey Johann Peter v. Ghelen - der Röm / Kaiserl. und Königl. Cathol. Majest. Hof. Buchdruckern."

The title page of the libretto provides the name of the theatre where Bernasconi's opera was produced - the "Teatro Privilegiato" - and the period - January 1737.19 This theatre, popularly called the theatre at the Carinthian gate (Theater am Kärntnertor or Kärntnertortheater), was from 1728 directed by two members of the imperial court staff: a tenor singer, Francesco Borosini, and a dancer, Joseph Carl Selliers..$^{20}$ The theatre was originally permitted only to produce comedies, but it gradually enlarged its repertoire to include also light operas, intermezzi and pasticci. and finally even full-scale opere serie. ${ }^{21}$ The years of the Turkish war (1737-1739) were also the years of a reduced imperial budget for operatic productions. ${ }^{22}$ "Cheaper" productions were probably sought as well by the impresario of the Kärntnertor Theatre - in these years the sole venue for major theatrical productions under the patronage of the Court. This situation perhaps explains why a dilettante - interestingly, called here "de Bernascone" - was engaged to compose the first carnival opera, and also why his score is preserved in the company of other compositions written during the same year by various court composers. ${ }^{23}$

17 The inner title page reads: "FLAVIO ANICIO / OLIBRIO / ATTO [a figure of a crowned eagle with a sword and a sceptre] PRIMO / MUSICA DI ANDREA DE BERNASCONI / DILETTANTE MILANESE / MDCCXXXVII." A-Wn; Mus.Hs. 18294/1-3.

18 A-Wst; A-68175. Sartori does not mention this libretto. I am indebted for this information to my colleague Jana Perutková who most kindly shared with me also a working copy of the libretto.

19 From the correspondence between Georg Adam Hoffmann (writing from Vienna) and his employer, the Moravian opera-lover Count Johann Adam von Questenberg, Lord of Jaroměrice, we learn that the opera was first performed before16 January. PERUTKOVÁ, Jana. Der glorreiche Nahmen Adami. Johann Adam Graf Questenberg (1678-1752) als Förderer der italienischen Oper in Mähren. Specula Spectacula 4. Wien: Hollitzer Verlag, 2015, p. 180.

20 On this theatre during the year under discussion, see SOMMER-MATHIS, Andrea. Höfisches Theater zwischen 1735 und 1745. Ein Wendepunkt? In Im Dienste einer Staatsidee. Künste und Künstler am Wiener Hof um 1740. Elisabeth Fritz-Hilscher (ed.). Wiener Musikwissenschaftliche Beiträge 24. Wien - Köln -Weimar: Böhlau Verlag, 2013, pp.109-123, and also PERUTKOVÁ, op. cit., pp. 183-205.

21 For the beginnings and early history of this theatre up to the early 1730s, see SOMMER-MATHIS, Andrea. Die Anfänge des Wiener Kärntnertortheaters zwischen deutschsprachiger Stegreifkomödie und Italienischer Oper. Divadelni revue, 2015, vol. 26, no. 2, pp. 139-152.

22 SOMMER-MATHIS, op. cit. (Höfisches Theater...), pp. 114-115.

23 The period immediately preceding the carnival season of 1737 witnessed major changes in the senior music staff of the Court chapel. In December 1736 the Vize-Kapellmeister Antonio Caldara died, and in the same year Giovanni Bononcini and Nicola Porpora arrived in Vienna. Giuseppe Bonno (also known as Joseph 
Bernasconi's Flavio Anicio Olibrio was actually not composed on a direct commission from the Court. It does not appear in Hadamowsky's list of official theatrical court music productions for the year $1737,{ }^{24}$ also, it is expressly mentioned in a contemporary source as not having being performed at the Court. ${ }^{25}$ The full score is preserved in three books handsomely bound in red leather with gilt decoration and a crowned eagle with sword and sceptre (the imperial emblem) in the centre of the cover. This binding differs from that of most of the other musical works in the court archives surviving from the same time: Antonio Caldara's Ciro riconosciuto of 1736, ${ }^{26}$ Giuseppe Bonno's serenata $\mathrm{La}$ Generosità di Artaserse ${ }^{27}$ and Carlo Arrigoni's untitled allegorical cantata (or serenata) ${ }^{28}$ plus his cantatas celebrating the name-days of the Emperor Charles VI and the Empress Elisabeth Christine,,$^{29}$ all dated 1737. This Carlo Arrigoni was at the time a chamber composer of Franz Stephan, Duke of Lorraine and the Emperor's son-in-law, who barely a year earlier had married the future Habsburg monarch Maria Theresa. ${ }^{30}$

These more official Court music pieces all include a list of singers, ${ }^{31}$ whereas in Bernasconi's score there is none, and its title page is followed immediately by the first page of the orchestral sinfonia. It seems more likely, on the other hand, that the singers of Bernasconi's Flavio Anicio Olibrio were those active in the Kärntnertor Theatre. Unfortunately, because of the lack of primary documentary materials no names can be securely linked to the production in January 1737. It can only be surmised that some of the singers documented for the 1735/1736 season or the year 1738 were likewise engaged for the 1737 carnival season. ${ }^{32}$

Bono) was engaged by the chapel in 1736 after having been sent by the Emperor to study music in Italy. See PERUTKOVÁ, op. cit., p. 179.

24 HADAMOWSKY, Franz. Barocktheater am Wiener Kaiserhof. Mit einem Spielplan (1626-1740). Vienna: A. Sexl, 1955, p. 114. These pieces were all smaller in scale: serenate, feste di camera or oratorios for the court chapel composed by Giovanni Bononcini, Nicola Porpora, Giuseppe Bono, Giuseppe Porsile and Maximilian Josef Hellmann. The official libretto for the Court carnival opera was actually Alessandro in Sidone, the choice of the court composer Giovanni Bononcini. See PERUTKOVÁ, op. cit., pp. 179-180.

25 PERUTKOVÁ, op. cit., p. 180.

26 A-Wn; Mus.Hs. 17177/1-3.

27 A-Wn; Mus.Hs. 18296.

28 The volume is untitled: A-Wn; Mus.Hs. 17606.

29 Allegorica, A-Wn; Mus.Hs. 17595, and Chi è costei, A-Wn; Mus.Hs. 17594, respectively.

30 On Arrigoni, see HILL, John Walter. Arrigoni, Carlo. In Grove Music Online. [cit. 2018-2-9]. URL: <http:// www.oxfordmusiconline.com.nukweb.nuk.uni-lj.si/subscriber/article/grove/music/01349> and PERUTKOVÁ, op. cit., pp. 180-181.

31 For example, the castrati Gaetano (soprano), Giovaninno and Cassati (alti), the bass singer Praun and Signora Reüter (soprano).

32 For the beginning of the 1735/1736 season the following singers are documented in Hoffmann's letters: Bambina (=Laura Bambini); Castrat; Catherl (= Katherina Mayer); Joseph (tenor); the Bassist Baczek; Barbiera and her husband from Italy (?Livia and Antonio Barbieri). PERUTKOVÁ, op. cit., pp. 201-202. For the year 1738 the information comes from the manuscript libretto of the opera La Girita: Francesco Arrigoni; Signora Galeta; Signora Giulia; Marianne Imer; Signora Rosa (?Rosa Pasquali); Catarina Zane. I am most grateful for this information to Andrea Sommer-Mathis, who very kindly shared with me her still unpublished materials. 
Nevertheless, all the above-mentioned musical scores from the year 1737, including Bernasconi's opera, have a common handwriting, or are at least written in the same type of scribal hand. It is a well-known fact that different court music copyists from that period often intentionally produced strikingly similar visual results. One name in particular was, however, suggested to me by Jana Perutková as a possible scribe for the first and third acts of Bernasconi's opera: Sebastian Senft, who had connections to the court as well as to the Kärntnertor Theatre..$^{33}$

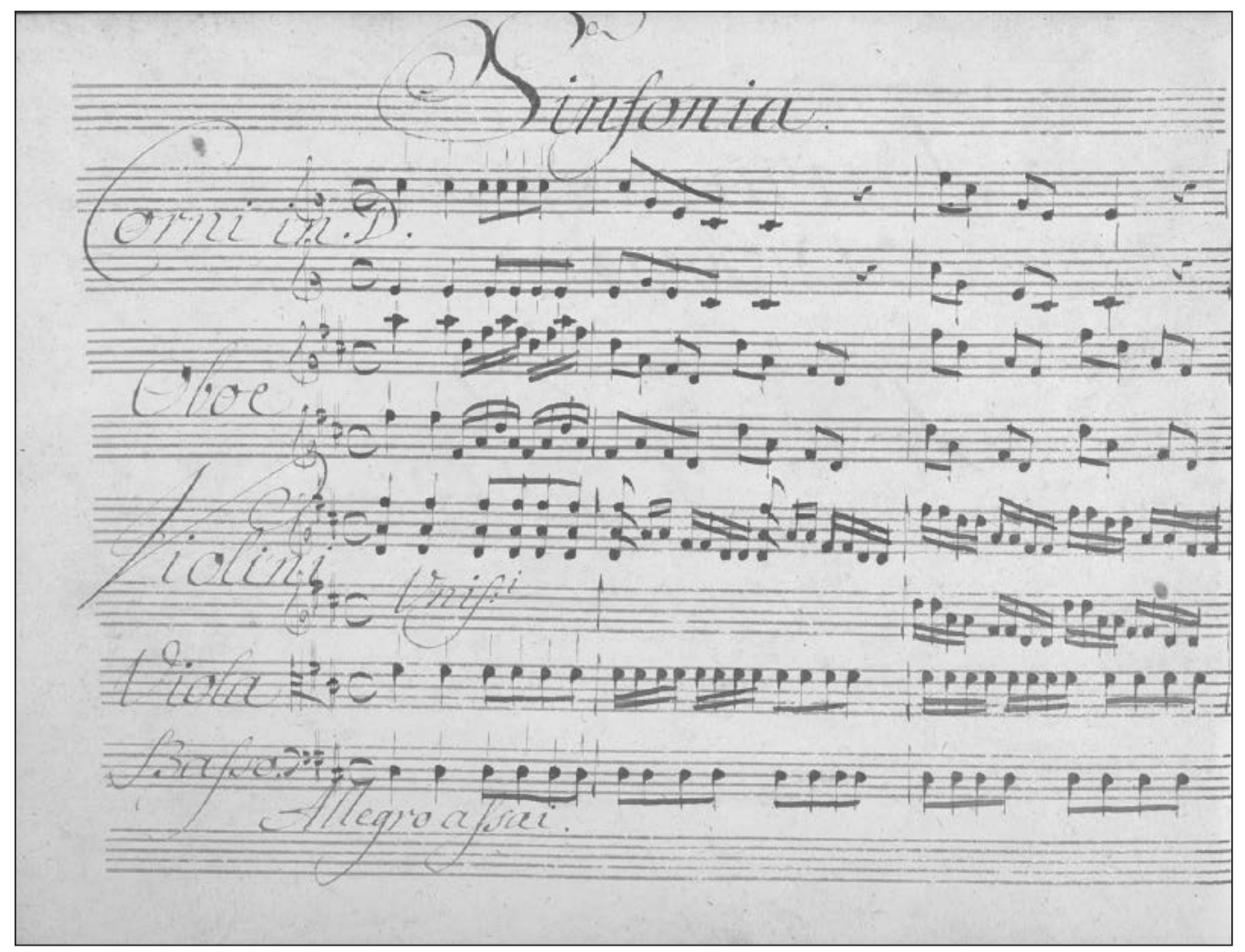

Fig. 2

The beginning of the introductory sinfonia in Andrea Bernasconi's 1737 Flavio Anicio Olibrio (A-Wn, Musiksammlung; Mus.Hs. 18294/1, with kind permission)

The neat score of Bernasconi's opera Flavio Anicio Olibrio begins straight away with the opening sinfonia for two horns, oboe, violins, viola and basso in $\mathrm{D}$. The opera includes arias for one tenor, one alto and five soprano singers: Flavio Anicio Olibrio (tenor), Placidia (soprano), Fedele (soprano), Ricimero (alto), Teodelinda (soprano), Olderico (soprano) and Massimo (soprano). The protagonist, whom we shall call Olibrio for

33 PERUTKOVÁ, op. cit., p. 41-43. More on the copying problematic associated with the Kärntnertor Theatre will be published in a forthcoming book by Jana Perutková, Andrea Sommer-Mathis and Reinhard Strohm. 
brevity, has four arias; Placidia and Fedele have the same number, while Teodelinda has five and Ricimero only three. Olderico and Massimo have only one aria each, in the third act. The score contains in all twenty-one standard da capo arias with long A-sections and much shorter B-sections plus one short, monosectional aria (II/1 Aure voi che respirate). The full list of arias in the score is given below in Appendix 2.

Each act begins with an instrumental sinfonia. The introductory one is for full standard orchestra with horns, oboes and string ensemble. The remaining two sinfonias are for horns and strings alone. Most of the arias have only a standard string accompaniment, but two of them have a full instrumental accompaniment: Leon piagato à morte (Ricimero, I/5) and Placidia's last aria, Il mio caro, e dolce amore (III/8), which is introduced by a lovely Menuetto for horns in F and strings. Olibrio's first aria, O viver più non voglio (I/1), has a standard instrumental accompaniment but prominent and copiously indicated dynamic marks. The basso parts are in some places for solo violoncello or violone. The first two acts conclude with arias - Fedele's Se amore in qualche petto (I/10) and Placidia's Bell'alme fortunate (II/8) - and the final act with a Marcia and a chorus. In the middle of Act II the score contains a terzetto for Placidia, Teodelinda and Ricimero: Mora Olibrio e pera il mondo. Taken as a whole, this is an opera seria following a standard pattern for its time.

The original libretto of Flavio Anicio Olibrio was written by Apostolo Zeno and Pietro Pariati and first set to music in $1707 / 1708$ by Francesco Gasparini for a production in Venice. The 1737 libretto for the Kärntnertor Theatre Vienna, the text of which is mostly identical with that in the preserved score, deviates greatly from the original 1707 libretto. ${ }^{34}$ Out of twenty-two arias in the 1737 version, only two (the first two arias in Act III, Fedele's Ama, e spera menzognera (III/1) and Olibrio's Ho dolor d'esser crudele (III/2), were taken from the Zeno-Pariati original libretto. The acts are also perceptibly shortened: Act I contains ten scenes instead of the original fourteen; Act II eight instead of fifteen; Act III eight instead of fourteen. In itself, this is nothing unusual.

It is also not surprising to find that the 1737 libretto found itself in some minor ways "emended" in the music score, especially in Act III. For example, one aria was given to a different character: Olibrio's Frà diletto, e frà timore (II/1) is in the libretto an aria for Teodelinda. The terzetto in scene four is new in the score and replaces recitatives present in the libretto (Scenes four to six). Scene six in Act II is also different. In the libretto there is an aria for Olibrio, Mi desti libertade, whereas in the score there is an aria for Teodelinda, Se per te cangia. Interestingly, the text of the second aria is written over an illegible original in a different ink and hand. The libretto also contains three arias in the final scene of Act II, each following on the other almost immediately - in fact, too closely. The score remedies this defect by placing each of the arias in a different later scene. Bernasconi's version as found in the score undoubtedly improves on the libretto as regards the omission of the mentioned recitatives and the altered distribution of the arias.

34 The title page is followed by the Argomento, which is taken word for word from the Zeno-Pariati original. Appearing on the same page is the list of Personaggi, shortened to comprise merely the seven main characters. There are no further texts besides the libretto of the opera itself. 
It may well be that the 1737 Viennese libretto, and in consequence the score, had to be prepared in great haste, so that to save time some existing arias by Bernasconi were reused. A closer look at Bernasconi's score indeed confirms the hypothesis that this opera was the author's own pasticcio rather than a completely new work. It includes, for example, four arias with Metastasian texts for Adriano in Siria, shown in bold in Appendix 2. All these arias match ones in the 1736 Milanese production of Bernasconi's Adriano, as discussed above, and receive confirmation for Bernasconi's authorship from other preserved musical manuscripts.

\section{Bernasconi's arias in the Attems collection}

One of these arias, Numi, se giusti siete, is preserved in as many as five other known manuscript sources (see Appendix 1). One of these comes from the collection in Maribor, belonging to the section of it that was originally owned by Countess Josepha von Attems, who at the time resided in Graz. ${ }^{35}$ All Bernasconi's soprano arias were copied for her or came into her possession before 1744, and all but one of them are presented in short score for voice and instrumental bass. In some instances, separate instrumental parts are also provided. These were undoubtedly intended for private use and were adapted to some extent with this in mind.

With as many as fifteen currently identified arias, Andrea Bernasconi ranks as the leading composer within this particular collection. The three most recent identifications have resulted from an analysis of Bernasconi's 1737 score for Vienna of Flavio Anicio Olibrio. Adding the four arias already identified as coming from his Adriano in Siria, there are in total seven arias from this production that were copied for Countess von Attems. All but one of these arias - the first on the list in Appendix 1 - were copied on a local paper of Carniolan and Styrian origin and by the same copyist. Bell'alme fortunate was notated as a short score with additional parts for two violins and viola, but Quel folle nocchiero and Basta tallora have no instrumental parts and have been slightly adapted. The original instrumental introduction is in those two cases omitted or significantly shortened, and the vocal parts have been transposed.

35 On Josepha von Attems, see KOKOLE, op. cit. (Migrations of Musical Repertoire...), pp. 342-343. 

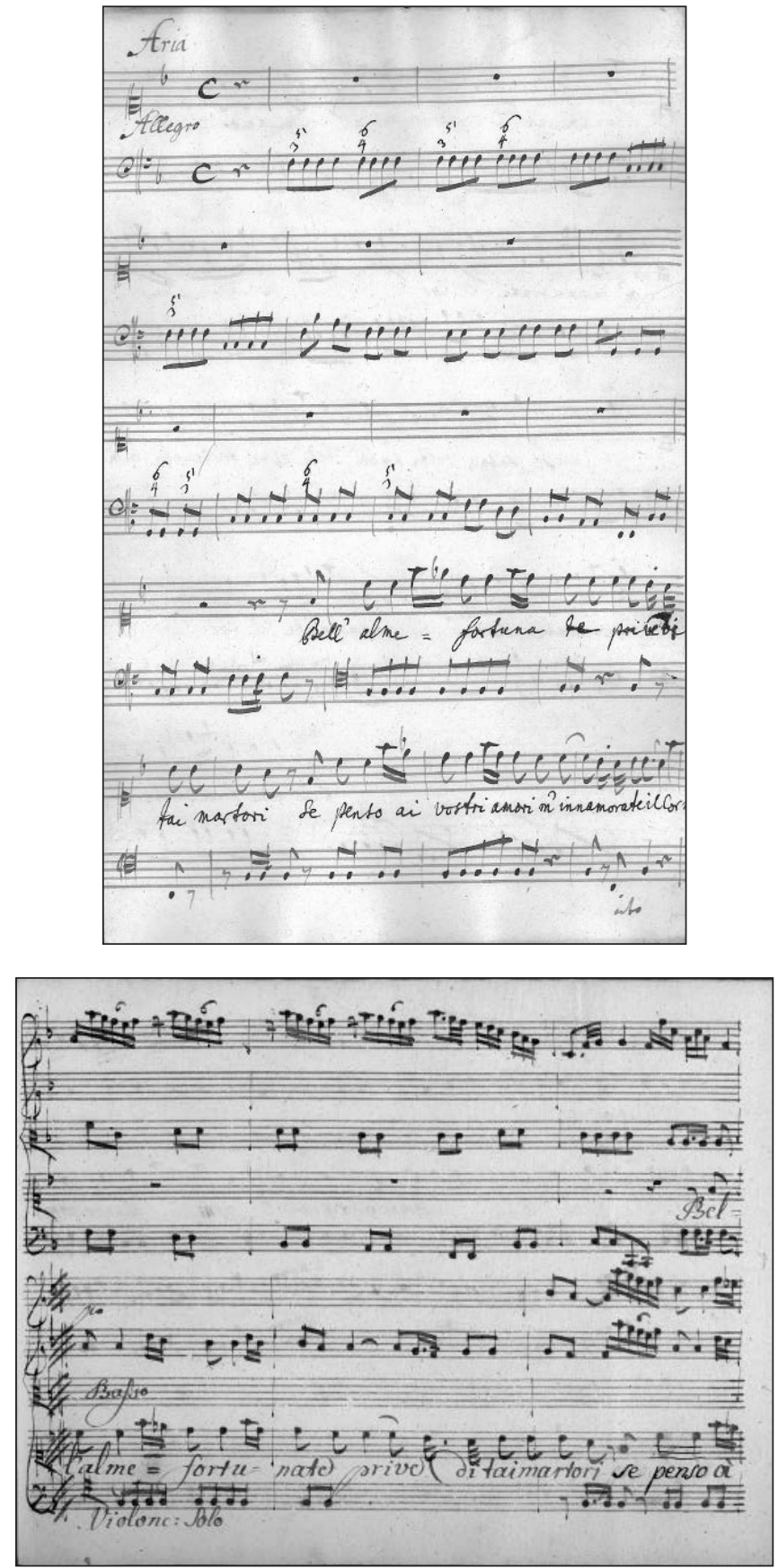

Figs. 3 and 4

The beginning of Bernasconi's aria Bell'alme fortunate from the Attems collection (SI-Mpa, no. 38, with kind permission) and the third page of the same aria from Flavio Anicio Olibrio (A-Wn, Musiksammlung; Mus.Hs. 18294/2, with kind permission) 
The first aria on the list of Bernasconi's compositions in the Attems collection (see Appendix 1), Oh Dio, mancar mi sento, ${ }^{36}$ differs from the other copies in two respects. It is written in full score for two violins, viola, soprano voice and instrumental bass, whereas the rest are in short score for voice and instrumental bass alone. Oh Dio, mancar mi sento is additionally written by a different hand; it was most probably copied by one of the music scribes serving the Viennese court - perhaps even the one responsible for the full score of Bernasconi's Flavio Anicio Olibrio preserved in Vienna (compare the scribal features of Fig. 2 above with those of Fig. 5 below). It would therefore appear that this particular manuscript was in fact brought to Graz in Styria from Vienna.

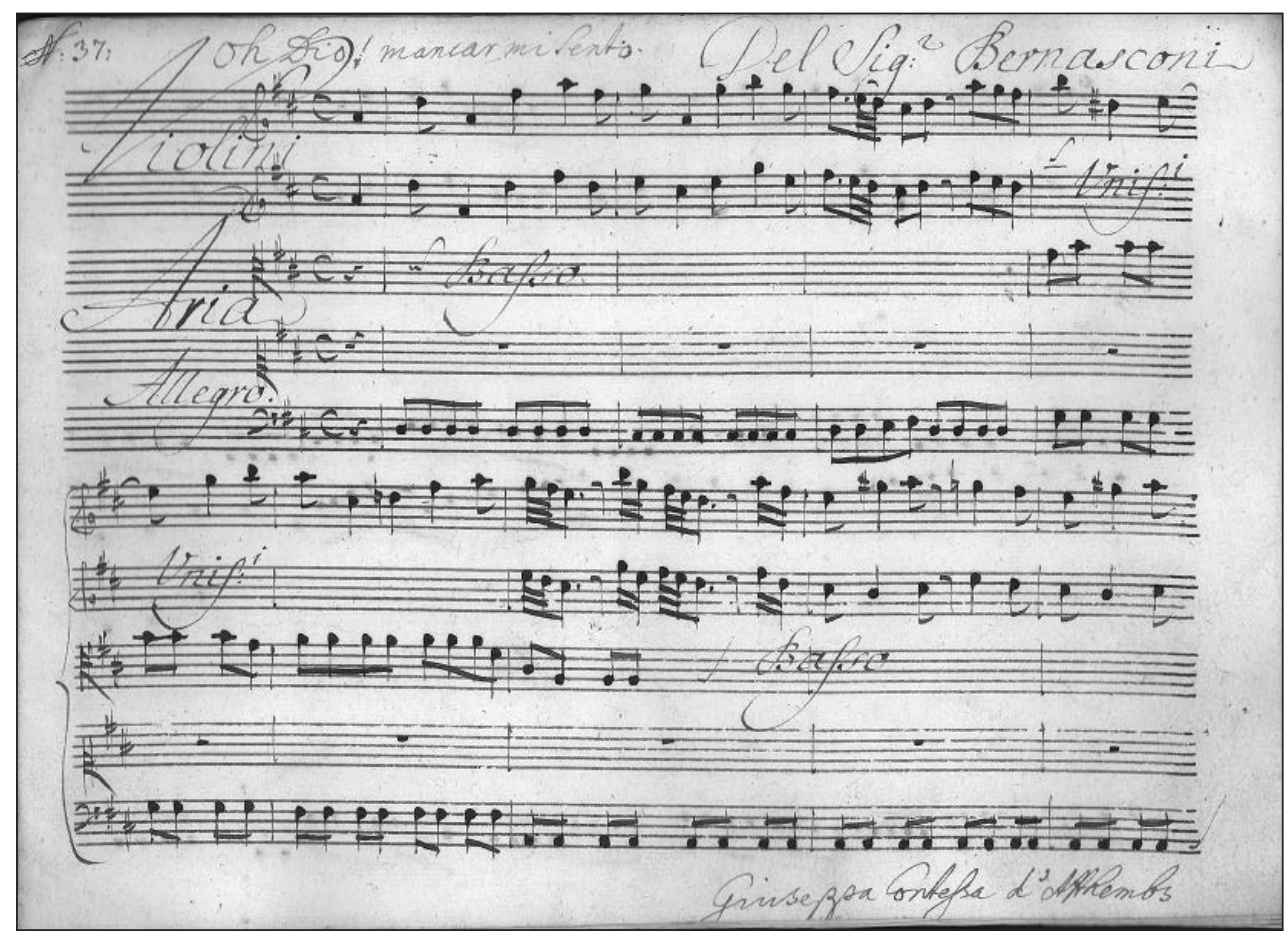

Fig. 5

The instrumental introduction of Bernasconi'a aria Oh Dio, mancar mi sento from the Attems collection (SI-Mpa, no. 16, with kind permission)

Viennese music circles were possibly also responsible for other works by Bernasconi in the same collection: not only the seven arias from Flavio Anicio Olibrio but also a Bernasconi aria, Amor mio la cruda sorte (SI-Mpa, no. 42), included in the Viennese pasticcio Il giorno felice, produced at the Kärntnertor Theatre in February $1737^{37}$ during the same 36 For a short description of two other contemporary manuscript sources of this aria, see KOKOLE, op. cit. (Did Andrea Bernasconi...), p. 257.

37 Il giorno felice / Der Glückseelige Tage. Vienna: Johann Peter van Ghelen, 1737. A digitized copy of I-Mb, 
carnival season as Flavio Anicio Olibrio and opening immediately after it. ${ }^{38}$ This aria, written for Licori in Act II ${ }^{39}$ has no indication of composer in the Maribor collection. It was identified via a concordant manuscript originally belonging to Count HatzfeldSchönstein, a nobleman from Bonn..$^{40}$ The Attems copy is preserved in a form of a short score with separate parts for two violins and viola and was written, probably in Graz, on a paper available locally.
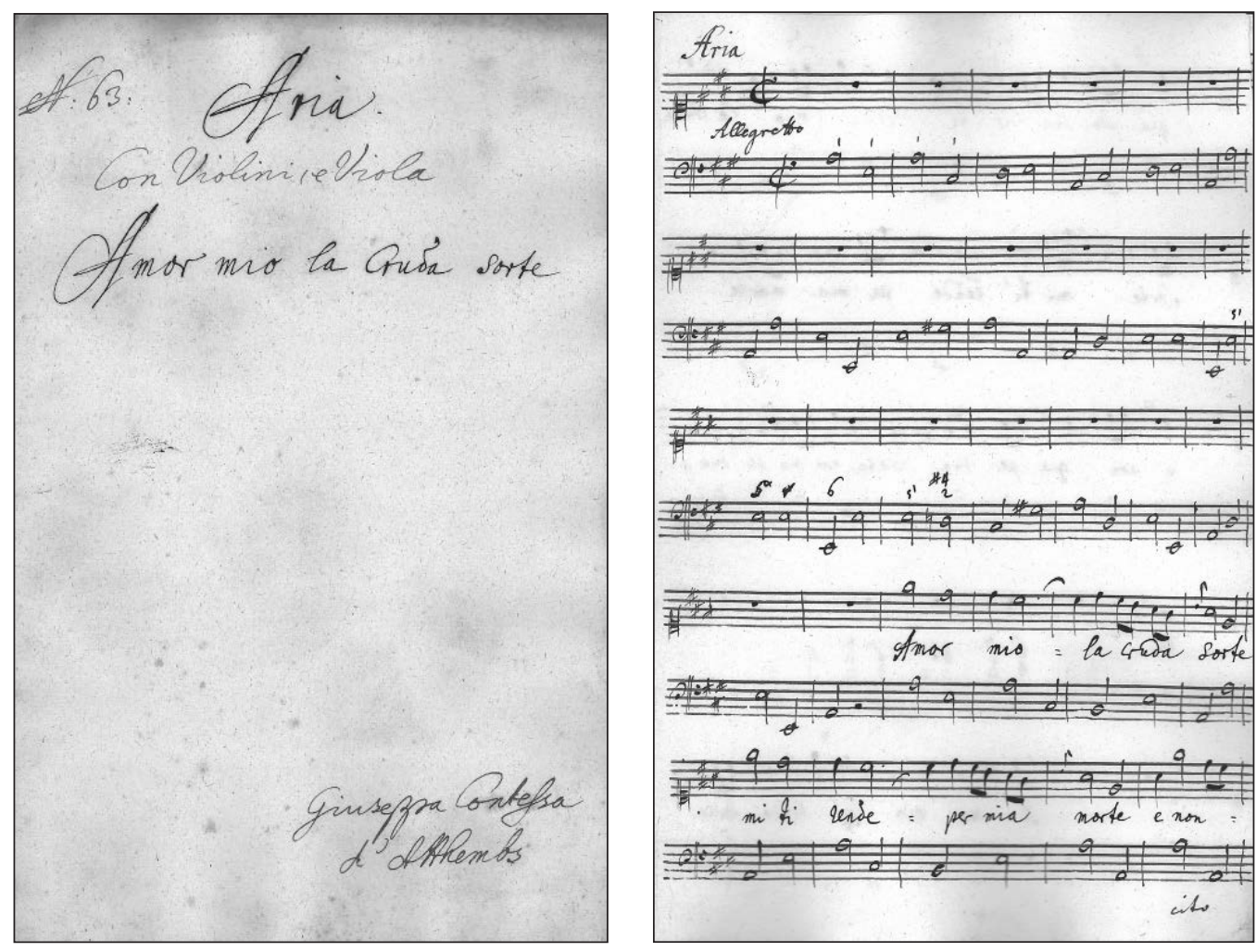

Fig. $6 a$ and $6 b$

The cover page and beginning of Bernasconi'a aria Amor mio la cruda sorte from the Attems collection (SI-Mpa, no. 42, with kind permission)

How, when and why this particular Viennese music repertoire reached the Attems household in Graz is at the moment still very difficult to guess. It is true that the name

Racc. Dramm. 3327 is available online via the OPAC SBN.

38 Interestingly, Flavio Anicio Olibrio was produced under the title La Tirannide debellata in a setting by Egidio Duni at the Royal and Ducal Theatre of Milan in the same Carnival season of 1736 as the Adriano in Siria discussed above.

39 On p. 28 of the original libretto.

40 For details, see KOKOLE, op. cit. (Did Andrea Bernasconi...), pp. 244-245. 
of the Countess is written on all of these pieces by Bernasconi, but when they were first performed in Vienna in 1737 she was still very young, no older than about fifteen years. So perhaps these were simply very popular pieces, possibly acquired in Vienna by some relative and given to her as material for singing practice at some later date. They could also have passed to her after 1739 from her newly wedded husband Ignaz Maria von Attems, who was apparently among the numerous musical contacts of Count Questenberg, a known admirer and supporter of Andrea Bernasconi and a keen follower of music events in Vienna and elsewhere. ${ }^{41}$ It cannot be excluded that she herself obtained this music at some point after May 1740, when Empress Elisabeth Christine made her a "Dame de l'ordre de la Croix de l'Etoile". ${ }^{42}$ The adaptations - for example, the transpositions found in numerous Attems copies - were possibly made especially for the Countess to suit her personal profile as a singer. In the absence of any proof, this must of course remain only a hypothesis. The only reasonably firm guess is that Bernasconi's music reached Graz, and later Slovenska Bistrica, via Vienna rather than directly from Italy.

\section{Bernasconi's earliest reception north of the Alps}

A further surmise that we can perhaps make is that music by Andrea Bernasconi in general reached regions north of the Alps earlier than has previously been thought, since Count Questenberg not only had Bernasconi's Flavio Anicio Olibrio performed at his residence in Jaroměřice, Moravia, later in the year 1737, but also considered commissioning a new opera with music by our composer. ${ }^{43}$ In October 1737 Bernasconi was presented by Questenberg's Hofmeister Hoffmann with the libretto of the opera Merope by Riccardo Broschi, to be given at Jaroměřice, and an invitation to attend the production. ${ }^{44}$ It appears that during this visit a chamber performance of Bernasconi's own new opera took place in the palace, as indicated above. In view of Bernasconi's personal contacts with the local nobility, an early popularity for his music in the Czech lands comes as no surprise, and this also explains the presence of various sacred contrafacta of his arias made for use in sacred contexts. There are at least two such contrafacta today held by the Archives of Prague Castle (CZ-Pak; see also Appendix 1, nos. 39 and 47), which were fitted to the music of Bernasconi's arias Il mio caro e dolce amore and Ah! che s'avessi il seno, both from his Flavio Anicio Olibrio ${ }^{45}$ and likewise preserved in the Attems collection.

41 PERUTKOVÁ, op. cit., p. 212 and KOKOLE, op. cit. (Migrations of Musical Repertoire...), p. 365 (footnote 80$)$.

42 KOKOLE, op. cit. (Migrations of Musical Repertoire...), p. 343 (footnote 8).

43 PERUTKOVÁ, op. cit., pp. 180-181.

44 Ibid.

45 A "pastorelle", Cur relinquis Deus, corresponds exactly in its musical incipit to the aria Il mio caro e dolce amore; the manuscript also informs us in its original title that it is "con Fondamento del Sig. Bernasconi". This Czech source dates from the mid-eighteenth century. The scribe and fitter of this music to its new, sacred text is identified as Josef Antonín Sehling, a Czech composer active between 1710 and 1756 (the year of his death). The other contrafactum, OJesu mi dilecte et sponse, is a retexting of the aria Ah che s'io avessi il seno. The composer 
It appears, further, that in 1737 his earlier opera Adriano in Siria, discussed at the beginning of this article, received a further production at the new Ducal Theatre in Stuttgart. ${ }^{46}$ Similarly to the libretto for the 1736 Milanese production, the preserved bilingual libretto for the 1737 one relating to Stuttgart does not mention the composer; on closer inspection, however, it becomes clear that this is essentially the same version: only two arias are different from ones present in the Milanese libretto. ${ }^{47}$ Contemporary sources confirm that Duke Carl Alexander of Württemberg was planning a Stuttgart performance of the Milanese Adriano in Siria already in late $1736 .{ }^{48}$ The same source also provides information on the engagement of Riccardo Broschi as Kapellmeister at the Württemberg court in November 1736. It has naturally been taken for granted that that Broschi was similarly the composer of the imported Milanese opera to be produced in Stuttgart, even though none of the sources explicitly mentions him as the author. My research on the Adriano in Siria produced in Milan has resulted into a new hypothesis and a different composer: Andrea Bernasconi. Broschi probably merely organized the production, though perhaps adding two replacement arias of his own. This production in Stuttgart of Bernasconi's Adriano in Siria could later have been one of the sources for the various copies of Bernasconi's early arias preserved in northern Europe.

Since Bernasconi's music for Adriano in Siria was evidently so popular, it is tempting to speculate further on another production - the Viennese one of 1743 at the Kärntnertor Theatre, which is known only through a surviving libretto that does not identify the composer. ${ }^{49}$ This appears, indeed, to be merely a shortened version of the same text with

is once again named in the title: "Aria O Jesu mi dilecte a Solo Canto, Violini 2, Viola e Fondamento. Del Sig. Bernasconi". This title was likewise penned by Sehling, but the music for the piece is in the hands of two different scribes.

46 On the music at the court of Württemberg-Stuttgart, see OWENS, Samantha. The Court of Württemberg-Stuttgart. In Music at German Courts, 1715-1760: Changing Artistic Priorities. Samantha Owens - Barbara M. Reul - Janice B. Stockigt (eds.). Woodbridge: Boydell Press, 2011, pp.165-195 (especially pp. 178-179 for the period under discussion).

47 ADRIANO IN SIRIA, RAPPRESENTATO E RECTATO NEL NUOVO TEATRO DUCALE IN STUCCARDA. 1737 / Der in Syrien Triumphierende Kayser HADRIANUS, Vorgestelt In Einer OPERA, Auf dem Hoch-Fürstlichen neuen THEATRO in Stuttgart. 1737. A digitized copy of I-Mb, Racc. Dramm. 3540 is available on-line through the OPAC SBN.

48 The document cited below was kindly shared with me by Samantha Owens, to whom I am very grateful and indebted. It is a letter from Duke Carl Alexander of Württemberg to Count Ludwig Andreas von Khevenhüller in Milan (dated Stuttgart, 10 November 1736): "Eu. Exc. haben den in meine Dienste zum Compositor di Musica anhero beruffenen Riccardo Broschi mit dero Vorschrifft begleithet, $u$. ich finde seine guthe Geschicklichkeit $u$. virtù dergestalt beschaffen, daß damit vollenkommentlich zufrieden bin, einfolglich mir angelegen seyn laßen werde, Ihme alle Gnad u. geneigten Willen zu erzeigen. [...]gestalten ich diese Gefälligkeit anderweith dancknehmig erkennen, vornehmlich aber auch Eu. Exc. höchstens obligirt seyn würde, wann dieselbe die hiernach specificirte Desseins von Operen Kleydern bey denen darain vermelten Personen, umb so bälder vor mich procuriren möchten, alß ich hiernechst die auf dem Theatro zu Mayland im vorigen Winter recitirte Opera Hadriano in Siria auch bey mir mit denen dazu behörigen Decorationen representiren zu laßen gesonnen bin.”. (Hauptstaatsarchiv Stuttgart, A7 Büschel 50). See also OWENS, op. cit., p. 179 (footnote 60).

49 ADRIANO IN SIRIA. DRAMMA PER MUSICA DA RAPPRESENTARSI NEL PRIVILEGIATO TEATRO Di Sua Maestà Reale, la Regina d'Ungheria, e di Boemia, $\mathcal{E}^{2}$. IN VIENNA. NELL'ANNO MDCCXLIII. Vienna: Johan Peter van Ghelen, [1743]. The scan of the original prints in Italian and in German by Giovan Pietro Van Ghelen of Vienna from 1743 (a digitized copy of I-Mb, Corniani Algarotti Racc. Dramm. 2336) is available online through 
the same arias that we know from Bernasconi's Adriano in Siria of 1736 for Milan. So there are - after all - many, and good, reasons for believing that Andrea Bernasconi's music achieved considerable popularity north of the Alps even before the mid-1740s.

\section{Appendix 1}

\section{The complete list of identified Bernasconi arias in SI-Mpa with their con- cordances}

16. Oh Dio! mancar mi sento (Metastasio: Adriano in Siria, III/7) also found in D-ROu \& B-Bc

22. Se non ti moro allato (Metastasio: Adriano in Siria, I/15)

also in US-Cu, US-FAy \& D-MÜs

25. Ch'io mai vi possa (Metastasio: Siroe, III/12)

27. Parto se vuoi cosi also in A-Wn (Flavio Anicio Olibrio)

28. Numi, se giusti siete (Metastasio: Adriano in Siria, I/11)

also in B-Bc, D-ROu, GB-Lbl, D-B [attributed to F. Finazzi] \& A-Wn (Flavio Anicio Olibrio)

29. Son sventurato (Metastasio: Adriano in Siria, III/9)

[only textual concordance]

30. È vero che oppresso la sorte (Metastasio: Adriano in Siria, I/8)

also in I-Mc, F-Sgs [sacred contrafactum]

38. Bell'alme fortunate

also in A-Wn (Flavio Anicio Olibrio)

39. Il mio caro e dolce amore

also in A-Wn (Flavio Anicio Olibrio) \& CZ-Pak (sacred contrafactum)

42. Amor mio la cruda sorte (Il giorno felice, Vienna 1737)

also in D-KNmi

47. Ah! che s'avessi il seno

also in A-Wn (Flavio Anicio Olibrio), I-GOs \& CZ-Pak (sacred contrafactum)

49. Quel folle nocchiero

also in A-Wn (Flavio Anicio Olibrio)

52. La raggion, gli affetti (Metastasio: Adriano in Siria, II/4)

also in D-ROu, B-Bc, I-Mc, I-Nc \& GB-Lbl

54. Basta tallora

also in A-Wn (Flavio Anicio Olibrio)

55. Digli, ch'è un infedele (Metastasio: Adriano in Siria, III/1)

also in D-ROu

the OPAC SBN. A copy of the German language version (translation by Johann Leopold van Ghelen, the printer's son) - which was printed separately - is preserved in A-Wst (Wienbiblithek im Rathaus; A 139.134). 


\section{Appendix 2}

\section{Arias in the extant score of Andrea Bernasconi's Flavio Anicio Olibrio of}

1737

FLAVIO ANICIO / OLIBRIO / ATTO [the figure of a crowned eagle with sword and sceptre] PRIMO / MUSICA DI ANDREA DE BERNASCONI / DILETTANTE MILANESE / MDCCXXXVII.

Sinfonia

I/2 Olibrio

I/3 Placidia

I/4 Teodelinda

I/ 5 Ricimero

I/8 Olibrio

I/9 Placidia

I/10 Fedele

\section{Sinfonia}

II/ 1 Teodelinda

II/ 1 Olibrio

II/2 Fedele

II/3 Ricimero

II/ 4 terzetto (Placidia, Teodelinda, Ricimero)

II/5 Fedele

II/ 6 Teodelinda

II/ 7 Teodelinda

II/ 8 Placidia

\section{Sinfonia}

III/ 1 Fedele

III/ 2 Olibrio

III/3 Teodelinda

III/4 Massimo

III/7 Ricimero

III/ 8 Placidia

III/ 8 Olderico

Marcia

CORO
$\mathrm{O}$ viver più non voglio

Prendi il mio sangue ancora

Basta tall'ora un sguardo

Leon piagato à morte

Parto, se vuoi così

Numi, se giusti siete

Se amore in qualche petto

Aure, voi che respirate

Frà diletto, e frà timore

Quel folle nocchiero

Saggio guerriero antico

Mora Olibrio, e pera il mondo

Ah che s'io avessi il seno

Se per te cangia

Sospiro mà spero

Bell'alme fortunate

Ama, e spera menzognera

Ho dolor d'esser crudele

Troppo facili noi siamo

Roma ti attende in campo

Meco perché si ingrata

Il mio caro, e dolce amore

Sprezza il furror del vento 


\section{Bibliography}

\section{Sources}

\section{LIBRETTI}

Adriano in Siria. Milan: Giuseppe Richino Malatesta, 1735.

Adriano in Siria / Der in Syrien Triumphierende Kayser HADRIANUS. Stuttgart: [the printer is not indicated], 1737.

Adriano in Siria. Vienna: Johann Peter van Ghelen, 1743.

Flavio Anicio Olibrio / Flavius Anicius Olibrius. Vienna: Johann Peter van Ghelen, 1737.

Il giorno felice / Der Glückseelige Tage. Vienna: Johann Peter van Ghelen, 1737.

MUSICAL MANUSCRIPTS

Österreichische Nationalbibliothek, Vienna. Flavio Anicio Olibrio. Musica di Andrea de Bernasconi Dilettante Milanese. [Vienna], 1737. Mus.Hs. 18294/1-3 Mus.

Pokrajinski arhiv Maribor, Gospoščina Bistriški grad, Musicalia, TE 67, AE 1.

OTHER SOURCES

Hauptstaatsarchiv Stuttgart, A7 Büschel 50.

\section{Literature}

GERBER, Ernst Ludwig. Bernasconi (Andrea). Historisch-Biographisches Lexicon der Tonkünstler, welches Nachrichten von dem Leben und Werken musikalischer Schriftsteller, berühmter Componisten, Sänger, Meister auf Instrumenten, Dilettanten, Orgel- und Instrumentenmacher, enthält. Vol. 1. Leipzig: Johann Gottlob Immanuel Breitkopf, 1790.

HADAMOWSKY, Franz. Barocktheater am Wiener Kaiserhof. Mit einem Spielplan (1626-1740). Vienna: A. Sexl, 1955.

HILL, John Walter. Arrigoni, Carlo. In Grove Music Online. [cit. 2018-2-9]. URL: <http://www. oxfordmusiconline.com.nukweb.nuk.uni-lj.si/subscriber/article/grove/music/01349>.

KÄGLER, Britta. Competition at the Catholic Court of Munich. Italian Musicians and Family Networks. In Musicians' Mobilities and Music Migrations in Early Modern Europe. Biographical Patterns and Cultural Exchanges. Gesa zur Nieden - Berthold Over (eds.). Bielefeld: Transcript Verlag, 2016, pp. 73-90: 81-84.

KOKOLE, Metoda. Metoda Kokole, Did Andrea Bernasconi Compose 'Adriano in Siria' Twice?. In Music Migration in the Early Modern Age: Centres and Peripheries - People, Works, Styles, Paths of Dissemination and Influence. Jolanta Guzy-Pasiak - Aneta Markuszewska (eds.). Warsaw: Liber Pro Arte, 2016, pp. 337-262.

KOKOLE, Metoda. Migrations of Musical Repertoire. The Attems Music Collection from Around 1744. In Musicians' Mobilities and Music Migrations in Early Modern Europe. Biographical Patterns and Cultural Exchanges. Gesa zur Nieden - Berthold Over (eds.). Bielefeld: Transcript Verlag, 2016, pp. 341-377.

KOKOLE, Metoda. The Lasting Musical Effects of the Italian Grand Tours of Ignaz Maria von Attems-Heiligenkreutz (1714-1762) and Thomas Gray (1716-1771). Arti musices, 2016, vol. 47, no. 1-2, pp. 79-101. 
MÜNSTER, Robert - CORNEILSON, Paul. Bernasconi, Andrea. In Grove Music Online. [cit. 20181-25]. URL: <http://www.oxfordmusiconline.com.nukweb.nuk.uni-lj.si/subscriber/article/ grove/music/02864>.

MÜNSTER, Robert. Bernasconi, Andrea. In Die Musik in Geschichte und Gegenwart Online. [2017-5-8]. URL: <https:/ / www-mgg-online-com.nukweb.nuk.uni-lj.si/article?id=mgg01419\&v=1.0\&rs=id4fd15a83-28b4-7db1-d9d8-3abf0bd26fe8>.

PERUTKOVÁ, Jana. Der glorreiche Nahmen Adami. Johann Adam Graf Questenberg (1678-1752) als Förderer der italienischen Oper in Mähren. Specula Spectacula 4. Wien: Hollitzer Verlag, 2015.

OWENS, Samantha. The Court of Württemberg-Stuttgart. In Music at German Courts, 1715-1760: Changing Artistic Priorities. Samantha Owens - Barbara M. Reul - Janice B. Stockigt (eds.). Woodbridge: Boydell Press, 2011, pp. 165-195.

SADGORSKI, Daniela. Andrea Bernasconi und die Oper am Münchner Kurfürstenhof 1753-1772. München: Herbert Utz Verlag, 2010.

SARTORI, Claudio. I libretti italiani a stampa dalle origini al 1800. Catalogo analitico con 16 indici (7 vols.). Cuneo: Bertola \& Locatelli, 1990-1994.

SOMMER-MATHIS, Andrea. Die Anfänge des Wiener Kärntnertortheaters zwischen deutschsprachiger Stegreifkomödie und Italienischer Oper. Divadelni revue, 2015, vol. 26, no. 2, pp. 139152.

SOMMER-MATHIS, Andrea. Höfisches Theater zwischen 1735 und 1745. Ein Wendepunkt? In Im Dienste einer Staatsidee. Künste und Künstler am Wiener Hof um 1740. Elisabeth Fritz-Hilscher (ed.). Wiener Musikwissenschaftliche Beiträge 24. Wien - Köln -Weimar: Böhlau Verlag, 2013, pp. 109-123.

WEISS. Eduard Josef. Andrea Bernasconi als Opernkomponist. Ph.D. Munich, 1923. 